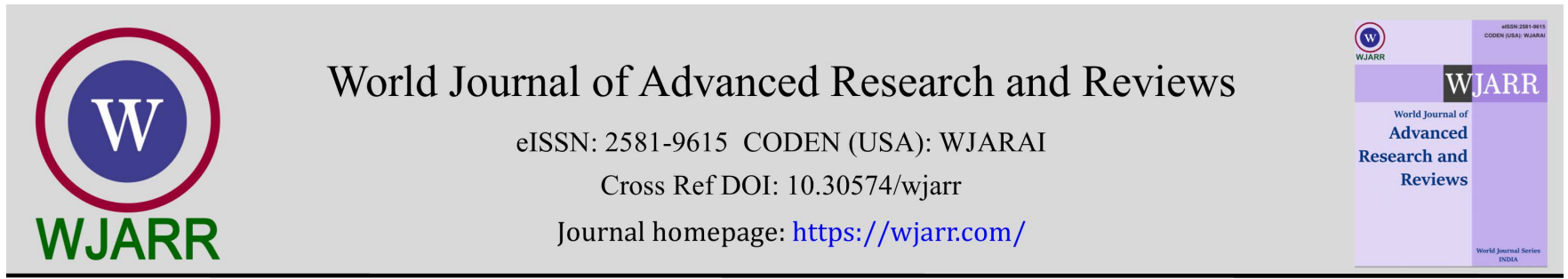

(RESEARCH ARTiCle)

\title{
Exogenous application of gibberellic acid and selenium to endorse quality and yield of fodder maize under rainfed conditions
}

\author{
Asma Hassan* and Lubna Ayub Durrani \\ Department of Agronomy, PMAS-Arid Agriculture University Rawalpindi. Pakistan.
}

World Journal of Advanced Research and Reviews, 2021, 12(02), 291-305

Publication history: Received on 27 September 2021; revised on 08 November 2021; accepted on 10 November 2021

Article DOI: https://doi.org/10.30574/wjarr.2021.12.2.0567

\begin{abstract}
Good quality and economical availability of fodder could be a substitute for crop production in the farming system of dryland areas. In Pakistan, the increasing demands of fodder crops for animal feed require immediate attention to find viable options for fodder production. Additionally, climate change, land detritions, and imbalanced use of chemicals led to an agro-ecological imbalance which needs to focus on mitigation strategies and practices. Therefore, the experiment was conducted three different rainfed areas of Punjab with aims to increase fodder maize quality by application of Gibberellic acid (GA3) and Selenium (Se) to overcome the forage scarcity issue in rainfed areas. The highest fresh biomass and leaf area were recorded by the application of GA75+Se0.75 followed by GA50+Se0.50 at 60 DAS. Similarly, the data about the silage quality traits indicated that more total dry matter (TDM), TDN, Crude protein (CP), neutral detergent fiber (NDF), Crude fiber (CF), acid detergent fiber (ADF), ash contents (AC) were recorded in Afgoi compared to Sohni Dhart 623. Among the experimental locations, the highest TDM, TDN, NDF, ADF and AC were found for the crop planted at NARC followed by URF, Koont and the least values of these traits were recorded for GRS, Attock. Among the different combinations of growth regulators, the highest TDM, TDN, CF, CP and NDF were recorded for GA75+Se0.75 followed by GA50+Se0.50. The above findings conclude that exogenously application of GA75+Se 0.75 plays a promising role in the improvement of fodder growth and quality parameters of silage in Afgoi verity at different water stress agroecological zones.
\end{abstract}

Keywords: Gibbrellic acid; Selenium; Fodder; Dryland; Biomass; Crude Protein

\section{Introduction}

Maize is recognized as the leading crop for fodder and is known for its multi-purpose uses such as for food, feed, forage and for the industry [1]. The popularity of the crop can be assessed as being referred to the miracle crop at many places as it has yield potential far higher than any other cereal. Like any other agricultural country, Pakistan Agri production system is based upon two major components including crops and animal husbandry. Being backbone of agricultural production, livestock generates $11 \%$ GDP and is known for $56 \%$ contributions to overall agriculture [2]. One of the recently published reports by Amir Waseem (2020) indicates that here were approximately 41.2 million buffaloes, 49.6 million cattle, 5.4 million donkeys,78.2 million goats and 30.9 million sheep in Pakistan (in addition to commercially grown poultry), and this increase demands the increase in fodder supply as well. Maize is a high energy feed which is one of the best green forage options as it contains the stalks, leaves and ears which are energy-rich feed sources for ruminant livestock. However, maize is rarely grown as fodder crop in this country, because the small farmers do not have enough resources of production, therefore they grow it as a cash crop instead. Another challenging situation that Pakistani growers face is the lack of proper irrigation arrangement to grow this crop. This is reported that approximately $66 \%$ of the maize has access to irrigation; the remainder is farmed under strictly rain-fed conditions. The average fodder production is $22.5 \mathrm{t} \mathrm{ha}^{-1}$ which is too low to meet even half of the maintenance requirements of the

\footnotetext{
${ }^{*}$ Corresponding author: Asma Hassan

Department of Agronomy, PMAS-Arid Agriculture University Rawalpindi. Pakistan.

Copyright $(2021$ Author(s) retain the copyright of this article. This article is published under the terms of the Creative Commons Attribution Liscense 4.0.
} 
present livestock population in the country [3]. The current situation is challenging as the rapid population increase the demand of livestock production on parallel basis. Thumb of rule is that ever-increasing livestock population requires the increase in the production as well productivity of fodder as well. As mentioned above, the increasing cultivation of cereal and cash crops has, in fact, contributed towards a decline in the area under fodder cultivation. Therefore, there is a tremendous pressure of livestock on available total feed and fodder, and to find viable options.

Fodder maize can produce higher amounts of palatable and fibrous fodder without any poisoning substance and is extensively used as silage in advanced countries [4]. Its digestibility is higher than sorghum, bajra, and other nonleguminous forage crops being traditionally grown in the country. But have no potential fodder maize drought-tolerant variety has been screened and recommended for Pothwar areas. Also, no investigations have been undertaken on the use of plant growth-promoting substances viz GA3 and nutrition improvement strategies for enhancing fodder maize quality which ultimately limits the production of quality maize silage. This situation demands envisaging some appropriate ways enabling the successful production of maize forage under water stress conditions which could be used for the preservation of silage to meet the fodder requirements during the critical fodder shortage period. One approach was to screen out drought-tolerant fodder maize genotypes under stressed conditions. While other could be the exogenous application of suitable growth regulators (GA3) for sufficient biomass production and selenium as a trace element for the improvement of fodder quality. In the present study, an effort was made to screen the moisture stress tolerant fodder maize varieties. For improving the stress tolerance and plant growth of fodder maize varieties GA3 was used along with the use of selenium (an essential nutrient for animals/human growth and metabolism) for producing quality fodder and silage for the livestock under the varied environment of Pothwar. To minimize the loss of silage nutritional quality is required to use of good quality plastic film [1].

Shortage of fodder production is the major limiting factor for livestock production in our country. There is about $2 \%$ reduction in fodder area in each decade along-with two important fodder scarcity periods, one in winter months (November-January) and the other in summer (May-June) further worsening the situation. In the experimental locations, there was a shortage of rainfall during the period of November-Jan and in June. Average temperature and rainfall were more ideal for maize crop growth and development at NARC, Islamabad as compared to URF Koont and Groundnut Research Station, Attock. Pakistan, rain-fed areas of Pothwar are scattered with small landholdings receive erratic and variable rains. Forages are the natural and cheapest option but their continuous supply in rainfed areas especially during cold winters (December-January) following hot months (May-June) always remains a hurdle for livestock's health and productivity. Due to severe shortage of green fodder in rainfed regions, animals are undernourished, thus subjected to poor health and low productivity [5]. During summer, sorghum is grown traditionally by the farmers as a fodder crop but it results in poor quality fodder due to high hydrocyanic acid content. The Pothwar rainfed area of Punjab, although produces more than $80 \%$ of rain-fed maize of Punjab province for grain. But it provides only $40-45 \%$ of the total fodder requirement. Of the total fodder requirement in Pothwar, presently $3 \%$ fodder requirement is met from maize fodder and the rest $97 \%$ demand of green fodder are fulfilled through sorghum (as major) and bajra and another non-legume crop as minor fodders [6].

There is no practice of silage production for supply as feed during lean periods [7]. Growing of maize as fodder could be the best solution to overcome the fodder deficiency in rainfed areas of the country. Among the major fodder crops in Pothwar region, sorghum is grown traditionally by the farmers as fodder crop but it results in poor quality fodder due to high hydrocyanic acid content. Growing of maize as fodder could be the better solution to overcome the fodder deficiency in rainfed areas of the country. Fodder maize is capable of producing higher amounts of palatable and fibrous fodder without any poisoning substance and is extensively used as silage in advanced countries. Its digestibility is higher than sorghum, bajra and other non-leguminous forage crops being traditionally grown in the country. But no potential fodder maize drought tolerant variety have yet been screened and recommended for Pothwar areas. Also no investigations have been undertaken on the use of plant growth promoting substances and nutrition improvement strategies for enhancing fodder maize quality which ultimately limits the production of quality maize silage. This situation necessitates envisaging some appropriate ways enabling the successful production of sufficient maize forage under water stress conditions which could be used for the preservation of silage to meet the fodder requirements during the critical fodder shortage period. One approach is to screen out drought tolerant fodder maize varieties under stressed conditions. Here an effort was made to screen the moisture stress tolerant fodder maize genotypes for enhanced yield and quality fodder/silage through the use of growth regulators and development of fodder production and silage preservation technology and its demonstration to the resource poor farmers of the project area. If current $3 \%$ contribution of maize fodder/silage in Pothwar is raised up to $10-15 \%$ after the completion of the project then it would be the successful achievement of the objectives of the project. Adoption of maize fodder production by the farmers, and skills development of the respective entrepreneurs could result in improvement in the socio-economic status of small resource poor famers of the project area due to value addition of maize fodder for silage. The project results would certainly offer an opportunity to improve the livelihood and prosperity of farming community on sustainable basis. 
Therefore experiment was designed with objective of enhancing fodder maize quality and silage preservation to overcome the forage scarcity issue in rain fed areas. Capacity building of different stakeholders (livestock farmers, extension workers, students and researchers and) through field demonstration of quality forage production and silage preservation technology in Pothwar.

\section{Material and methods}

\subsection{Assessment of quality perimeters of maize fodder}

The two best performing drought tolerant fodder maize varieties/ hybrids (Sohni dehrti-626 and Afgoi) selected were sown at three agro-ecological locations i.e. at low (Attock), medium (University Research Farm, Koont (Gujjar Khan) and high (Rawalpindi) rainfall areas of Pothwar during autumn season. The size of each experimental unit was maintained as $5 \mathrm{~m} \times 5 \mathrm{~m}$. Randomized complete block design RCBD) with split plot arrangement was used with three replications. Main plots were used for sowing fodder maize varieties/ hybrids and the subplots were used for foliar spray of different combinations of GA3 and Se at 4-6 leaf stage of maize plant.

The leaf area was estimated according to [8] Dry matter accumulation (g plant-1) was determined by collecting five plants at random from each plot. Soon after harvest each sample was weighed to determine its fresh weight. Each plant sample was chaffed, thoroughly mixed and then oven dried to estimate the dry weight plant-1.Leaf area index (LAI) was calculated as the ratio of leaf area to land area (Hunt, 1978). Crop growth rate (g m-2 day-1) was calculated as proposed by Hunt (1978). Leaf area duration (LAD) was determined according to the formula suggested by Hunt (1978).Net assimilation rate (NAR) was calculated by using the formula of Hunt (1978).For silage making all the steps i.e. fodder cutting, chopping, pressing and baling are done through fodder cutter, fodder chopper, pressing and baling machine respectively. This technology is practiced by progressive large farmers who can afford its cost. But overall the small farmer is the dominant community of rainfed Pothwar. Therefore, it demands the silage preservation technology for such resource poor farmers. In this project an effort was also made for small farmers and experimentations was done to finalize the technology for farmers having 3 to 5 animals in the project area. For silage purpose 5 - $10 \%$ fodder maize was harvested at 50\% heading stage /at milking stage. The maize fodder was chopped and ensiled in small plastic bags for making silage and silage quality parameters (dry matter (DM), crude protein (CP), crude fiber (CF), total digestible nutrients (TDN), neutral detergent fiber (NDF), acid detergent fiber (ADF) and total ash) were determined to standardize the silage making technology of maize fodder crop and its demonstration to small resource poor farmers at three experimental locations of low, medium and high rainfall areas of Pothwar. However, the mechanized silage making and preservation were practiced and demonstrated at one location (University Research Farm, Chakwal road, Rawalpindi).

\subsubsection{Silage quality parameters determination/measurements}

Nitrogen in silage was determined according to [9]. The crude fiber was calculated with the following formula as described by (Harris, 1970). The nitrogen free extract (NFE) was determined by difference after the analysis of all other items in proximate analysis on dry matter percent basis by following equation [10].

The ether extract was determined by the formula as

Ether Extract $(\mathrm{EE})=(\mathrm{We}-\times 100) / \mathrm{wd}$

The total digestible nutrient computed by using the equation of [11].

The ash samples were kept for mineral determination. Ash percentage was calculated by using the following formulae (AOAC, 1994). The acid detergent fiber was determined as

$\mathrm{ADF}(\mathrm{DM}$ basis $)=\left(\mathrm{W} 3 \mathrm{~A}=\pi \mathrm{r}^{\wedge} 2-(\mathrm{W} 1 \times \mathrm{C} 1)\right) \times 100 \mathrm{~W} 2 \times \mathrm{DM}$

\section{Results and discussion}

\subsection{Weather of Experimental Areas}

The meteorological data (Figure-1) shows the average maximum temperature (30.94 0C) and rainfall (116.48 mm) recorded at NARC, Islamabad. The average maximum temperature at Attock (36.0 0C) exceeds the URF Koont (Gujjar Khan) location (32.28 0C). However the average rainfall received at Attock location (108.95 mm) was higher than that 
at URF Koont, Gujjar Khan (97.47 mm). Total rainfall and mean relative humidity were positively correlated, while all the temperature extremes showed the negative correlation with maize crop yield [12]. Weather variability has great impact on crop yield variability [13]. Availability of moisture; potential evaporation and temperature are identified short-term weather fluctuations which affect maize growth and yield [14].

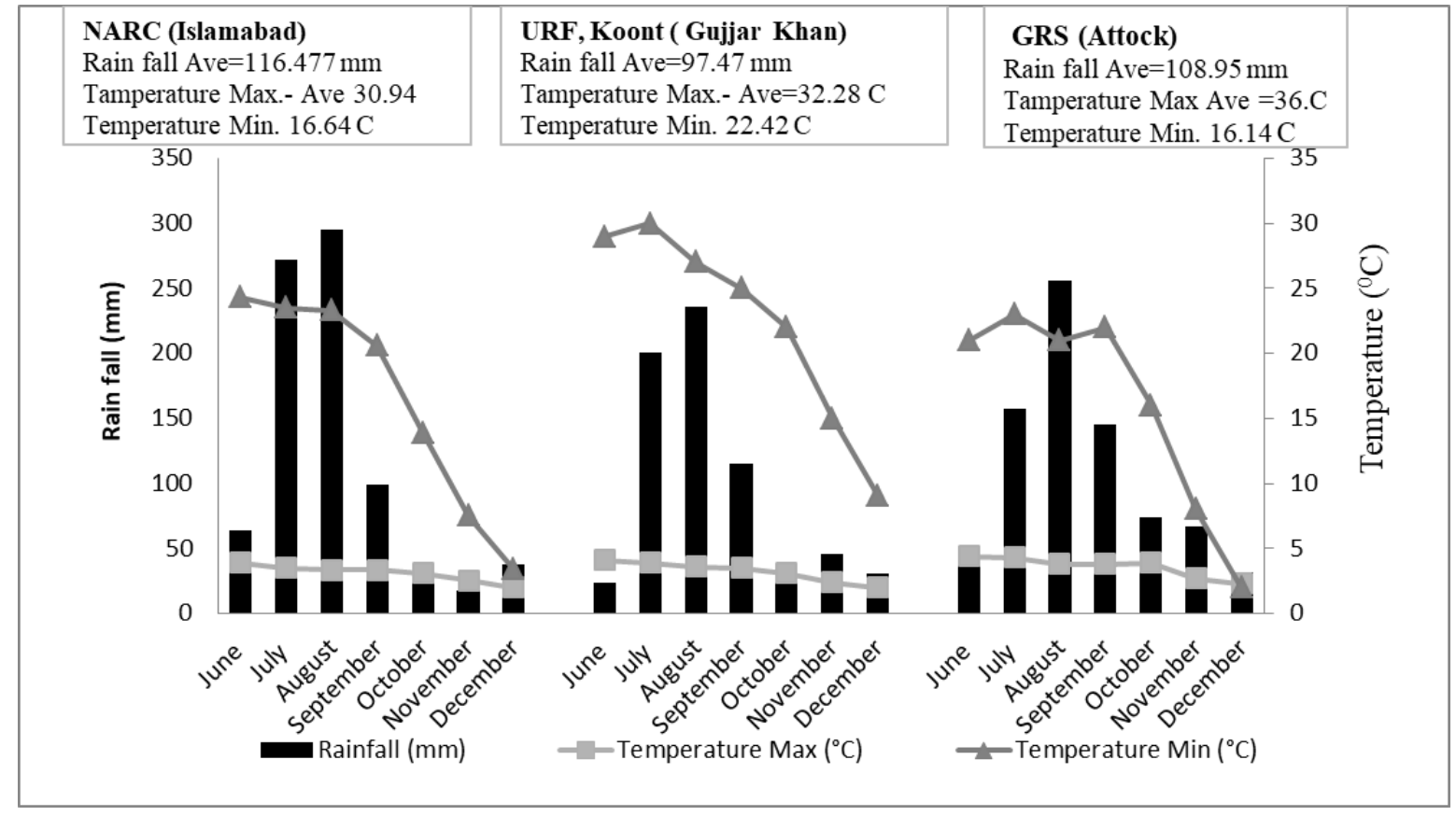

Figure 1 Weather data recorded at NARC (Islamabad), URF Koont, and GRS (Attock) during maize fodder growing season $(2019-20)$

\subsection{Plant Height (cm) of Maize Varieties/hybrids at Harvesting}

The different treatments viz. varieties (Afgoi, and SohniDharti-623), growth regulators levels $(0$, GA75+Se0.75 and GA50+Se0.50) and locations (NARC, Islamabad), URF Koont, Gujjar Khan and GRS, Attock) had significant effect on the overall plant height (Table 1) (PH). Among the locations, the crop planted at NARC gained the highest plant height $(162.69 \mathrm{~cm})$ followed by the plant height at URF Koont, Gujjar khan $(144.20 \mathrm{~cm})$ and GRS, Attock (129.08 cm) respectively. Among the varieties, the highest PH was recorded in variety Afgoi $(183.7 \mathrm{~cm})$ followed by Sohni dehrti623 at NARC. Similar trend for plant height was observed for other two locations for both the varieties. The interactive effect of the growth regulators treatments (GA3 +Se) showed that plant height reached to the plateau value of $195.2 \mathrm{~cm}$ in V1 with the foliar application of GA75+Se 0.75 followed by $185.3 \mathrm{~cm}$ withGA50+Se0.50 and the lowest PH value was recorded in Shoni Dahrti-623 with control (GA0+Se0) at NARC. Plant height at NARC was followed by plant height by that at URF Koont, Gujjar khan and GRS, Attock respectively with same trend for both the varieties. Foliar application of GA3 significantly improved the plant height in maize fodder [15]. Application of GA3 improved the plant tolerance to water deficit and significantly enhanced the plant height by increasing the cell division and elongation [16].

Table 1 Effect of different locations and combined levels of growth regulators on plant height (cm) of maize fodder varieties/hybrids at harvesting

\begin{tabular}{|c|c|c|c|c|c|c|}
\hline Treatments / Locations & \multicolumn{2}{|c|}{$\begin{array}{l}\text { NARC (Islamabad) } \\
\text { (Loc-1) }\end{array}$} & \multicolumn{2}{|c|}{$\begin{array}{l}\text { URF Koont (Gujjar Khan) } \\
\text { (Loc-2) }\end{array}$} & \multicolumn{2}{|c|}{$\begin{array}{l}\text { GRS (Attock) } \\
\text { ( Loc-3) }\end{array}$} \\
\hline Varieties & Afgoi & $\begin{array}{c}\text { Sohni } \\
\text { Dharti }-623\end{array}$ & Afgoi & $\begin{array}{c}\text { Sohni } \\
\text { Dharti-623 }\end{array}$ & Afgoi & $\begin{array}{c}\text { Sohni } \\
\text { Dharti-623 }\end{array}$ \\
\hline Control & $170.7 \mathrm{c}$ & $135.5 \mathrm{~h}$ & $156.5 \mathrm{e}$ & $118.4 \mathrm{j}$ & $145.4 \mathrm{fg}$ & $105.4 \mathrm{k}$ \\
\hline $\mathrm{GA}_{75}+\mathrm{Se}_{0.75}$ & $195.2 \mathrm{a}$ & $148.5 \mathrm{f}$ & $175.4 \mathrm{c}$ & $127.5 \mathrm{i}$ & $156 \mathrm{e}$ & $122.5 \mathrm{ij}$ \\
\hline $\mathrm{GA}_{50}+\mathrm{Se}_{0.50}$ & $\begin{array}{c}185.3 \\
b\end{array}$ & $140.9 \mathrm{~g}$ & $165 \mathrm{~d}$ & 122.4 & $135.8 \mathrm{~h}$ & $109.4 \mathrm{k}$ \\
\hline
\end{tabular}




\subsection{Fresh Biomass Yield ( $t$ ha-1) of Fodder Maize Varieties/Hybrids at 30 Days}

Fresh biomass at 30 days (Table 2) showed that different growth regulator treatments (GA and Se), maize varieties (Afgoi and Sohni Dharti-623) and locations (NARC, Koont URF and Attock) had significant effect on fresh biomass. Among the location, maize crop sown at NARC produced the highest fresh biomass (930.5 $\left.\mathrm{tha}^{-1}\right)$ followed by that at Koont URF, Gujjar Khan (732.33 t ha-1) and GRS, Attock (281.95 $\mathrm{t} \mathrm{ha}^{-1}$ ). More fresh biomass was recorded for Afgoi (335 $t \mathrm{ha}^{-1}$.) followed by Sohni Dharti-623 (303.64 tha-1). Combined application of graded levels of GA3+Se indicated that fresh biomass of maize fodder at 60 DAS was 370.70 tha-1with the foliar application of GA75+Se0.75 followed with GA50+Se0.50 (325.80 $\mathrm{t} \mathrm{ha}^{-1}$ ). Interactive effect of different locations and graded levels of growth regulators on fresh biomass yield $\left(\mathrm{t} \mathrm{ha}^{-1}\right)$ of fodder maize varieties/hybrids at 30 DAS was found non-significant.

Table 2 Effect of different locations and graded levels of growth regulators on fresh biomass yield ( $t$ ha-1) of fodder maize varieties/hybrids at 30 Days

\begin{tabular}{|l|c|c|c|c|c|c|}
\hline \multicolumn{1}{|c|}{$\begin{array}{c}\text { Treatments / } \\
\text { Locations }\end{array}$} & \multicolumn{2}{c|}{$\begin{array}{c}\text { NARC (Islamabad) } \\
\text { (Loc-1) }\end{array}$} & $\begin{array}{c}\text { URF Koont (Gujjar Khan) } \\
\text { (Loc-2) }\end{array}$ & \multicolumn{2}{c|}{$\begin{array}{c}\text { GRS (Attock) } \\
\text { (Loc-3) }\end{array}$} \\
\hline Varieties & Afgoi & $\begin{array}{c}\text { Sohni Dharti- } \\
\mathbf{6 2 3}\end{array}$ & Afgoi & Varieties & Afgoi & $\begin{array}{c}\text { Sohni Dharti- } \\
\mathbf{6 2 3}\end{array}$ \\
\hline Control & $310 \mathrm{~ns}$ & $289.5 \mathrm{~ns}$ & $278 \mathrm{~ns}$ & $255.4 \mathrm{~ns}$ & $225.8 \mathrm{~ns}$ & $215.7 \mathrm{~ns}$ \\
\hline $\mathrm{GA}_{75}+\mathrm{Se}_{0.75}$ & $432 \mathrm{~ns}$ & $395.7 \mathrm{~ns}$ & $385.8 \mathrm{~ns}$ & $327.5 \mathrm{~ns}$ & $372.8 \mathrm{~ns}$ & $310.4 \mathrm{~ns}$ \\
\hline $\mathrm{GA}_{50}+\mathrm{Se}_{0.50}$ & $410 \mathrm{~ns}$ & $371.4 \mathrm{~ns}$ & $317.5 \mathrm{~ns}$ & $288.9 \mathrm{~ns}$ & $288.7 \mathrm{~ns}$ & $278.3 \mathrm{~ns}$ \\
\hline
\end{tabular}

\subsection{Fresh Biomass Yield (t ha-1) of Fodder Maize Varieties/hybrids at 60 Days}

Among the locations, the highest fresh biomass was produced at NARC (930.75 tha-1)) followed by that at URF Koont, Gujjar khan (732.33 t ha-1) and GRS, Attock (651.62 t ha-1). More fresh biomass was recorded for Afgoi (802.46 t ha1.) followed by Sohni Dharti-623 (740.68t ha-1 (Table 3). Combined pplication of growth regulators (GA3+Se) indicated that the fresh biomass of maize fodder at 60 DAS was $800.59 t$ ha-1with the foliar application of GA75+Se 0.75 followed by that withGA50+Se0.50 (769.13 t ha-1) and the least value was recorded in control. Application of GA3 significantly increased vegetative growth which finally increased the dry matter accumulation [17].

Table 3 Effect of different locations and graded levels of growth regulators on fresh biomass yield ( $t$ ha-1) of fodder maize varieties/hybrids at 60 days

\begin{tabular}{|c|c|c|c|c|c|c|}
\hline $\begin{array}{c}\text { Treatments / } \\
\text { Locations }\end{array}$ & \multicolumn{2}{|c|}{$\begin{array}{c}\text { NARC (Islamabad) } \\
\text { (Loc-1) }\end{array}$} & \multicolumn{2}{c|}{$\begin{array}{c}\text { URF Koont (Gujjar Khan) } \\
\text { (Loc-2) }\end{array}$} & \multicolumn{2}{c|}{$\begin{array}{c}\text { GRS (Attock) } \\
\text { (Loc-3) }\end{array}$} \\
\hline Varieties & Afgoi & $\begin{array}{c}\text { Sohni } \\
\text { Dharti-623 }\end{array}$ & Afgoi & Varieties & Afgoi & $\begin{array}{c}\text { Sohni Dharti- } \\
\mathbf{6 2 3}\end{array}$ \\
\hline Control & $853.4 \mathrm{~ns}$ & $808.5 \mathrm{~ns}$ & $661.8 \mathrm{~ns}$ & $592.4 \mathrm{~ns}$ & $587.4 \mathrm{~ns}$ & $489.6 \mathrm{~ns}$ \\
\hline $\mathrm{GA}_{75}+\mathrm{Se}_{0.75}$ & $1047 \mathrm{~ns}$ & $985.5 \mathrm{~ns}$ & $875.5 \mathrm{~ns}$ & $820.5 \mathrm{~ns}$ & $778.5 \mathrm{~ns}$ & $776.5 \mathrm{~ns}$ \\
\hline $\mathrm{GA}_{50}+\mathrm{Se}_{0.50}$ & $986.7 \mathrm{~ns}$ & $903.4 \mathrm{~ns}$ & $736.4 \mathrm{~ns}$ & $707.4 \mathrm{~ns}$ & $695.4 \mathrm{~ns}$ & $582.3 \mathrm{~ns}$ \\
\hline
\end{tabular}

\subsection{Leaf Area Index of Fodder Maize Varieties/hybrids at 30 Days}

Statistical analysis of data showed that different growth regulator treatments (GA and Se), maize varieties/hybrids (Afgoi and Sohni Dharti-623) and locations (NARC, URF Koont, Gujjar Khan and GRS, Attock) had significant effect on mean values of plant LAI (Table 4). Among the locations, the crop planted at NARC produced the highest LAI (0.6021) followed by that at URF Koont, Gujjar Khan (0.5192) and GRS, Attock (0.4413). Among the varieties/hybrids, greater LAI value was recorded for Afgoi (0.5510) followed by Sohni Dharti-623 (0.4908). Combined use of the treatments $(\mathrm{GA} 3+\mathrm{Se})$ indicated the highest value of LAI (0.5665) was recorded with the foliar application of GA75+Se0.75 at $30 \mathrm{DAS}$ followed with GA50+Se0.50 (0.5250). Interactive effect of different locations and graded levels of growth regulators on LAI of fodder maize varieties/hybrids at 30 DAS was found non-significant. 
Table 4 Effect of different locations and graded levels of growth regulators on LAI of fodder maize varieties/hybrids at 30 days

\begin{tabular}{|l|l|l|l|l|l|l|}
\hline $\begin{array}{c}\text { Treatments / } \\
\text { Locations }\end{array}$ & \multicolumn{1}{|c|}{$\begin{array}{c}\text { NARC (Islamabad) } \\
\text { (Loc-1) }\end{array}$} & \multicolumn{2}{c|}{$\begin{array}{c}\text { URF Koont (Gujjar Khan) } \\
\text { (Loc-2) }\end{array}$} & \multicolumn{2}{c|}{$\begin{array}{c}\text { GRS (Attock) } \\
\text { ( Loc-3) }\end{array}$} \\
\hline Varieties & Afgoi & $\begin{array}{l}\text { Sohni } \\
\text { Dharti-623 }\end{array}$ & Afgoi & Varieties & Afgoi & $\begin{array}{l}\text { Sohni } \\
\text { Dharti-623 }\end{array}$ \\
\hline Control & $0.587 \mathrm{~ns}$ & $0.525 \mathrm{~ns}$ & $0.512 \mathrm{~ns}$ & $0.426 \mathrm{~ns}$ & $0.410 \mathrm{~ns}$ & $0.370 \mathrm{~ns}$ \\
\hline $\mathrm{GA}_{75}+\mathrm{Se}_{0.75}$ & $0.689 \mathrm{~ns}$ & $0.605 \mathrm{~ns}$ & $0.605 \mathrm{~ns}$ & $0.510 \mathrm{~ns}$ & $0.515 \mathrm{~ns}$ & $0.466 \mathrm{~ns}$ \\
\hline $\mathrm{GA}_{50}+\mathrm{Se}_{0.50}$ & $0.615 \mathrm{~ns}$ & $0.589 \mathrm{~ns}$ & $0.560 \mathrm{~ns}$ & $0.499 \mathrm{~ns}$ & $0.462 \mathrm{~ns}$ & $0.422 \mathrm{~ns}$ \\
\hline
\end{tabular}

\subsection{Leaf Area Index of Fodder Maize Varieties/hybrids at 60 Days}

Among the locations, the crop planted at NARC gave the highest value of lAI (2.660 cm2) followed by that at URF Koont, Gujjar Khan (2.1967 cm2) and GRS, Attock (1.8390 cm2). Among the varieties/hybrids, greater LAI was recorded for Afgoi (2.398) followed by Sohni Dharti-623 (2.066) (Table 5). Combined use of the treatments (GA3+Se) showed that leaf area index at 30 days was the highest with the foliar application of GA75+Se0.75 (2.5136) followed by that with GA50+Se0.50 (2.1984). Interactive effect reflected that the highest leaf area index at 60 days was recorded in Afgoi 3.20 $\mathrm{cm} 2$ with the application of GA75 $+\mathrm{Se}_{0.75}$ at NARC followed by the Sohni Dahrti $\left(2.967 \mathrm{~cm}^{2}\right)$. The same trend was found for the other two locations. The lowest value of LAI was recorded for Sohni Dharti-623 $\left(1.366 \mathrm{~cm}^{2}\right)$ variety under controlled conditions. Application of GA3 significantly enhanced the leaf area of maize fodder might be due to the increased division and elongation of the cell. Similar findings were reported by [18] who found that GA3 foliar application significantly increased the cell division in meristematic zones of the plant which finally increased the length of the cells. These results are in concordance with the by the findings of [19-16] GA3 application improved the water deficit tolerance in maize and showed positive effects on the growth of leaves. The increased leaf area with GA3application was also reported by [20].

Table 5 Effect of different locations and graded levels of growth regulators on LAI of fodder maize varieties/hybrids at 60 days

\begin{tabular}{|c|c|c|c|c|c|c|}
\hline \multirow{2}{*}{$\begin{array}{c}\begin{array}{c}\text { Treatments / } \\
\text { Locations }\end{array} \\
\text { Varieties }\end{array}$} & \multicolumn{2}{|c|}{$\begin{array}{c}\text { NARC (Islamabad) } \\
\text { (Loc-1) }\end{array}$} & \multicolumn{2}{|c|}{$\begin{array}{c}\text { URF Koont (Gujjar Khan) } \\
\text { (Loc-2) }\end{array}$} & \multicolumn{2}{|c|}{$\begin{array}{c}\text { GRS (Attock) } \\
\text { (Loc-3) }\end{array}$} \\
\hline & Afgoi & $\begin{array}{c}\text { Sohni Dharti- } \\
623 \\
\end{array}$ & Afgoi & Varieties & Afgoi & $\begin{array}{c}\text { Sohni } \\
\text { Dharti-623 }\end{array}$ \\
\hline Control & $2.357 \mathrm{ef}$ & 2.176 ghi & $2.108 \mathrm{hij}$ & 1.8721 & $1.972 \mathrm{jkl}$ & $1.366 \mathrm{n}$ \\
\hline $\mathrm{GA}_{75}+\mathrm{Se}_{0.75}$ & $3.260 \mathrm{a}$ & $2.967 \mathrm{~b}$ & $2.571 \mathrm{~d}$ & $2.232 \mathrm{fgh}$ & $2.123 \mathrm{hij}$ & $1.926 \mathrm{kl}$ \\
\hline $\mathrm{GA}_{50}+\mathrm{Se}_{0.50}$ & $2.786 \mathrm{c}$ & $2.411 \mathrm{de}$ & $2.312 \mathrm{efg}$ & 2.082 hijk & $2.024 \mathrm{ijkl}$ & $1.572 \mathrm{~m}$ \\
\hline
\end{tabular}

\subsection{Leaf Area Duration of Fodder Maize Varieties/hybrids}

Table 6 Effect of different locations and graded levels of growth regulators on LAD of fodder maize varieties/hybrids

\begin{tabular}{|c|c|c|c|c|c|c|}
\hline $\begin{array}{c}\text { Treatments / } \\
\text { Locations }\end{array}$ & \multicolumn{2}{|c|}{$\begin{array}{c}\text { NARC (Islamabad) } \\
\text { (Loc-1) }\end{array}$} & $\begin{array}{c}\text { URF Koont (Gujjar Khan) } \\
\text { (Loc-2) }\end{array}$ & \multicolumn{3}{c|}{$\begin{array}{c}\text { GRS (Attock) } \\
\text { (Loc-3) }\end{array}$} \\
\hline Varieties & Afgoi & $\begin{array}{c}\text { Sohni Dharti- } \\
\mathbf{6 2 3}\end{array}$ & Afgoi & Varieties & \multicolumn{2}{c|}{$\begin{array}{c}\text { Afgoi } \\
\mathbf{6 2 3}\end{array}$} \\
\hline Control & $44.184 \mathrm{~cd}$ & $39.315 \mathrm{e}$ & $35.744 \mathrm{fg}$ & $40.530 \mathrm{~d}$ & $34.482 \mathrm{fgh}$ & $26.055 \mathrm{i}$ \\
\hline $\mathrm{GA}_{75}+\mathrm{Se}_{0.75}$ & $59.2485 \mathrm{a}$ & $47.65875 \mathrm{c}$ & $39.575 \mathrm{e}$ & $53.5965 \mathrm{~b}$ & $41.151 \mathrm{de}$ & $35.8875 \mathrm{fg}$ \\
\hline $\mathrm{GA}_{50}+\mathrm{Se}_{0.50}$ & $51.0225 \mathrm{ab}$ & $43.094 \mathrm{~d}$ & $37.30 \mathrm{fg}$ & $45.019 \mathrm{~cd}$ & $38.729 \mathrm{f}$ & $29.931 \mathrm{gh}$ \\
\hline
\end{tabular}


The crop planted at NARC had more LAD (48.934 days) followed by that at URF Koont, Gujjar Khan(40.738 days) and GRS, Attock (34.083 days). Among the varieties/ hybrids, the largest LAD was recorded for Afgoi (44.128 days) followed by Sohni Dharti-623 (38.376 days) (Table 6). Combined use of the treatments (GA3+Se) indicated that LAD was the highest with GA75+Se0.75 (46.186 days) and the least was in control (36.519 day). Interactive effect of growth regulator treatments, varieties/hybrids and locations reflected that the highest LAD was in Afgoi (59.248 days) with the application of GA75+Se0.75 at NARC followed by that of Sohni Dahrti 623(51.022 days) at same location with the application of GA50+Se0.50. The lowest value of LAD was recorded for Sohni Dharti 623 (26.055 days) under the control treatment.

\subsection{Net Assimilation Rate (gm-2day-1) of Fodder Maize Varieties/hybrids}

Among the locations, the crop planted at NARC had more NAR was similar (19.287 g m-2 day-1) at Koont URF (Chakwal road) (18.262 $\mathrm{g} \mathrm{m}^{-2}$ day$^{-1}$ ) and Attock (19.457 $\mathrm{g} \mathrm{m}^{-2}$ day-1). Among the varieties, highest net assimilation rate was recorded for Afgoi (19.606 $\mathrm{g} \mathrm{m}^{-2}$ day $^{-1}$ ) followed by Sohni Dharti-623 (18.262 g m-2 day-1) (Table 7). Combined use of the treatments $(\mathrm{GA} 3+\mathrm{Se})$ indicated that net assimilation rate was highest with GA75+Se0.75 $\left(19.623 \mathrm{~g} \mathrm{~m}-2 \mathrm{day}^{-1}\right)$ and followed by GA50+Se0.50 (18.181 $\mathrm{g} \mathrm{m}^{-2}$ day $\left.^{-1}\right)$ and control (16.262 $\mathrm{g} \mathrm{m}^{-2}$ day-1 $^{-1}$ The findings of the present study were found in accordance with [19] exogenous application of GA3 not only improved the drought tolerance in maize but also improves growth, NAR and yield under normal as well as scarce water conditions. Interactive effect of different locations and graded levels of growth regulators on NAR $\left(\mathrm{gm}^{-2} \mathrm{day}^{-1}\right)$ of fodder maize varieties/hybrids was found non-significant.

Table 7 Effect of different locations and graded levels of growth regulators on NAR (gm-2day-1) of fodder maize varieties/hybrids

\begin{tabular}{|c|c|c|c|c|c|c|}
\hline $\begin{array}{c}\text { Treatments / } \\
\text { Locations }\end{array}$ & \multicolumn{2}{|c|}{$\begin{array}{c}\text { NARC (Islamabad) } \\
\text { (Loc-1) }\end{array}$} & $\begin{array}{c}\text { URF Koont (Gujjar Khan) } \\
\text { (Loc-2) }\end{array}$ & \multicolumn{2}{c|}{$\begin{array}{c}\text { GRS (Attock) } \\
\text { (Loc-3) }\end{array}$} \\
\hline Varieties & Afgoi & $\begin{array}{c}\text { Sohni } \\
\text { Dharti-623 }\end{array}$ & Afgoi & Varieties & Afgoi & $\begin{array}{c}\text { Sohni } \\
\text { Dharti-623 }\end{array}$ \\
\hline Control & $20.981 \mathrm{~ns}$ & $21.770 \mathrm{~ns}$ & $16.611 \mathrm{~ns}$ & $19.896 \mathrm{~ns}$ & $18.756 \mathrm{~ns}$ & $24.746 \mathrm{~ns}$ \\
\hline $\mathrm{GA}_{75}+\mathrm{Se}_{0.75}$ & $16.151 \mathrm{~ns}$ & $16.431 \mathrm{~ns}$ & $16.497 \mathrm{~ns}$ & $17.188 \mathrm{~ns}$ & $17.403 \mathrm{~ns}$ & $16.683 \mathrm{~ns}$ \\
\hline $\mathrm{GA}_{50}+\mathrm{Se}_{0.50}$ & $19.611 \mathrm{~ns}$ & $20.775 \mathrm{~ns}$ & $19.364 \mathrm{~ns}$ & $18.790 \mathrm{~ns}$ & $18.981 \mathrm{~ns}$ & $20.167 \mathrm{~ns}$ \\
\hline
\end{tabular}

\subsection{Crop Growth Rate $\left(\mathrm{gm}^{-2} \mathrm{day}^{-1}\right)$ of Fodder Maize Varieties/hybrids}

Table 8 Effect of different locations and combined levels of growth regulator on CGR (gm ${ }^{-2} \mathrm{day}^{-1}$ ) of fodder maize varieties/hybrids

\begin{tabular}{|c|c|c|c|c|c|c|}
\hline $\begin{array}{c}\text { Treatments / } \\
\text { Locations }\end{array}$ & \multicolumn{2}{|c|}{$\begin{array}{c}\text { NARC (Islamabad) } \\
\text { (Loc-1) }\end{array}$} & \multicolumn{2}{c|}{$\begin{array}{c}\text { URF Koont (Gujjar Khan) } \\
\text { (Loc-2) }\end{array}$} & \multicolumn{2}{c|}{$\begin{array}{c}\text { GRS (Attock) } \\
\text { (Loc-3) }\end{array}$} \\
\hline Varieties & Afgoi & $\begin{array}{c}\text { Sohni } \\
\text { Dharti-623 }\end{array}$ & Afgoi & $\begin{array}{c}\text { Sohni Dharti- } \\
\mathbf{6 2 3}\end{array}$ & \multicolumn{2}{c|}{$\begin{array}{c}\text { Afgoi } \\
\text { Sohni } \\
\text { Dharti-623 }\end{array}$} \\
\hline Control & $20.607 \mathrm{~ns}$ & $19.735 \mathrm{~ns}$ & $12.537 \mathrm{~ns}$ & $14.402 \mathrm{~ns}$ & $14.855 \mathrm{~ns}$ & $14.377 \mathrm{~ns}$ \\
\hline $\mathrm{GA}_{75}+\mathrm{Se}_{0.75}$ & $17.512 \mathrm{~ns}$ & $16.147 \mathrm{~ns}$ & $13.29 \mathrm{~ns}$ & $12.563 \mathrm{~ns}$ & $10.532 \mathrm{~ns}$ & $9.64 \mathrm{~ns}$ \\
\hline $\mathrm{GA}_{50}+\mathrm{Se}_{0.50}$ & $19.716 \mathrm{~ns}$ & $18.810 \mathrm{~ns}$ & $17.252 \mathrm{~ns}$ & $14.651 \mathrm{~ns}$ & $13.745 \mathrm{~ns}$ & $10.782 \mathrm{~ns}$ \\
\hline
\end{tabular}

Crop planted at NARC (17.225 $\left.\mathrm{g} \mathrm{m}^{-2} \mathrm{day}^{-1}\right)$ had more CGR followed by that at URF Koont, Gujjar Khan (13.616 $\mathrm{g} \mathrm{m}^{-2}$ days$\left.{ }^{1}\right)$ and GRS, Attock (12.321 $\mathrm{g} \mathrm{m}^{-2}$ day $^{-1}$ ) respectively (Table 8). Among the varieties/hybrids the highest CGR was recorded similar in Afgoi (14.48 $\mathrm{g} \mathrm{m}^{-2} \mathrm{day}^{-1}$ ) and Sohni Dharti-623 (14.58 g m-2 days-1). Combined use of the treatments $(\mathrm{GA} 3+\mathrm{Se})$ indicated that crop growth rate was highest inGA75+Se0.75control $17.552 \mathrm{~m}^{-2} \mathrm{day}^{-1}$ and followed by 13.281 with GA50+Se0.50. (14.760 $\mathrm{g} \mathrm{m}^{-2}$ day $\left.^{-1}\right)$ and control (10.881 $\mathrm{g} \mathrm{m}^{-2} \mathrm{day}^{-1}$ ).Improved growth might be due to optimum uptake of various nutrients, as GA3 found to play an important role in enhancing the N, P, K, content [21]. [18] GA3 significantly increased the cell division in meristematic zones of the plant and hence the ability of the plant to absorb nutritive material which finally lead to the increase of length and growth rate of cells [18]. Spray of GA3 prolonged the growth period and increased vegetative growth [16]. Exogenously applied hormone during early growth stage protects the membrane structures by improving stress tolerance under water deficit and provides energy for growth [22]. 
Interactive effect of different locations and graded levels of growth regulators on CGR (gm-2 day ${ }^{-1}$ ) of fodder maize varieties/hybrids was found non-significant.

\subsection{Leaf Area (cm2 plant-1) of Fodder Maize Varieties/hybrids at 30 Days}

Growth regulator treatments (GA3 and Se), maize varieties/hybrids (Afgoi and Sohni Dharti-623) and locations (NARC, URF Koont, Gujjar Khan and GRS, Attock) had significant effect on over all mean value of leaf area 30 days (Table 9). Among the locations, the crop planted at NARC had more LAI (6021.4) followed by that at URF Koont, Gujjar Khan (5192.2) and GRS, Attock (4413.4). Among the varieties/hybrids, the highest LAI was recorded similar in Afgoi (5510.1) and followed by Sohni Dharti-623 (497.9). Combined use of the treatments (GA3+Se) indicated that crop growth rate was highest with GA75+Se0.75 5654.4 and with GA50+Se0.50 (5249.7) followed by 4722.7 with controlled. Interaction was non-significant.

Table 9 Effect of different locations and graded levels of growth regulators on leaf area (cm2 per plant) of fodder maize varieties/hybrids at 30 days

\begin{tabular}{|c|c|c|c|c|c|c|}
\hline $\begin{array}{c}\text { Treatments / } \\
\text { Locations }\end{array}$ & \multicolumn{2}{|c|}{$\begin{array}{c}\text { NARC (Islamabad) } \\
\text { (Loc-1) }\end{array}$} & \multicolumn{2}{c|}{$\begin{array}{c}\text { URF Koont (Gujjar Khan) } \\
\text { (Loc-2) }\end{array}$} & \multicolumn{2}{c|}{$\begin{array}{c}\text { GRS (Attock) } \\
\text { (Loc-3) }\end{array}$} \\
\hline Varieties & Afgoi & $\begin{array}{c}\text { Sohni } \\
\text { Dharti- } \\
\mathbf{6 2 3}\end{array}$ & Afgoi & Varieties & Afgoi & $\begin{array}{c}\text { Sohni } \\
\text { Dharti-623 }\end{array}$ \\
\hline Control & $5877 \mathrm{~ns}$ & $5259 \mathrm{~ns}$ & $5127 \mathrm{~ns}$ & $4262 \mathrm{~ns}$ & $4102.2 \mathrm{~ns}$ & $3707 \mathrm{~ns}$ \\
\hline $\mathrm{GA}_{75}+\mathrm{Se}_{0.75}$ & $6890 \mathrm{~ns}$ & $6053 \mathrm{~ns}$ & $6058 \mathrm{~ns}$ & $5109 \mathrm{~ns}$ & $5152.5 \mathrm{~ns}$ & $4664 \mathrm{~ns}$ \\
\hline $\mathrm{GA}_{50}+\mathrm{Se}_{0.50}$ & $6152 \mathrm{~ns}$ & $5896 \mathrm{~ns}$ & $5602 \mathrm{~ns}$ & $4993 \mathrm{~ns}$ & $4628 \mathrm{~ns}$ & $4226 \mathrm{~ns}$ \\
\hline
\end{tabular}

\subsection{Leaf Area (cm2 per plant) of Fodder Maize Varieties/hybrids at 60 Days}

Effect of growth regulator treatments in maize varieties/hybrids (Afgoi and Sohni Dharti-623) and locations (NARC, URF Koont, Gujjar Khan and GRS, Attock) had significant effect on over all mean value of leaf area 60 days (Table 10). Among the locations, the crop planted at NARC had more LAI (2601) followed by that at URF Koont, Gujjar Khan, (21957) and GRS, Attock (18308). Among the varieties/hybrids, the highest LAI was recorded similar in Afgoi (23908) and followed by Sohni Dharti-623 (25136). Combined use of the treatments (GA3+Se) indicated that crop growth rate was highest with GA75+Se0.75 (25139) and with GA50+Se0.50 (21984) followed by with controlled. Interaction was non-significant. Interactive effect of growth regulator treatments, varieties/hybrids and locations reflected that the highest LA was in Afgoi (326) with the application of GA75+Se0.75 at NARC followed by that of Sohni Dahrti 623(29677) at same location with the application of GA50+Se0.50. The lowest value of LAD was recorded for Sohni Dharti 623 (13622) under the control treatment.

Table 10 Effect of different locations and combined levels of growth regulators on leaf area (cm2 per plant) of fodder maize varieties/hybrids at 60 days

\begin{tabular}{|c|c|c|c|c|c|c|}
\hline $\begin{array}{c}\text { Treatments / } \\
\text { Locations }\end{array}$ & \multicolumn{2}{|c|}{$\begin{array}{c}\text { NARC (Islamabad) } \\
\text { (Loc-1) }\end{array}$} & $\begin{array}{c}\text { URF Koont (Gujjar Khan) } \\
\text { (Loc-2) }\end{array}$ & \multicolumn{2}{c|}{$\begin{array}{c}\text { GRS (Attock) } \\
\text { (Loc-3) }\end{array}$} \\
\hline Varieties & Afgoi & $\begin{array}{c}\text { Sohni } \\
\text { Dharti-623 }\end{array}$ & Afgoi & Varieties & Afgoi & $\begin{array}{c}\text { Sohni } \\
\text { Dharti-623 }\end{array}$ \\
\hline Control & $23579 \mathrm{ef}$ & $21761 \mathrm{hij}$ & $21082 \mathrm{hij}$ & $18725 \mathrm{jkl}$ & $19727 \mathrm{ijkl}$ & $13662 \mathrm{n}$ \\
\hline $\mathrm{GA}_{75}+\mathrm{Se}_{0.75}$ & $32609 \mathrm{a}$ & $29677 \mathrm{~b}$ & $25714 \mathrm{~d}$ & $22325 \mathrm{fgh}$ & $21231 \mathrm{ghi}$ & $19261 \mathrm{kl}$ \\
\hline $\mathrm{GA}_{50}+\mathrm{Se}_{0.50}$ & $27862 \mathrm{c}$ & $24117 \mathrm{de}$ & $23127 \mathrm{efg}$ & $20826 \mathrm{hijk}$ & $20242 \mathrm{ijkl}$ & $15728 \mathrm{~m}$ \\
\hline
\end{tabular}

\subsection{Total Dry Matter Accumulation (TDM) of Maize Fodder Silage}

Among the locations, the crop planted at NARC produced the highest TDM $(8.00 \mathrm{t}$ ha-1) that was statistically nonsignificant with that at URF Koont (7.82 $\mathrm{t} \mathrm{ha}^{-1}$ ). The lowest TDM (7.44 $\mathrm{t} \mathrm{ha}^{-1}$ ) was recorded at GRS, Attock (Loc-3). Similarly maximum TDM was recorded in Afgoi (8.17 t ha-1) followed by Sohni Dahrti 623 (7.34 tha ${ }^{-1}$ ). Comparison of 
the growth regulator treatments means showed that TDM reached to the plateau value of $9.07 \mathrm{tha}-1$ with the application of GA75+Se0.75 followed by GA50+Se0.50 (8.19 tha-1). The lowest TDM (6.75 t ha-1) was obtained in control. The interactive effect of all the factors was found statistically non-significant $(p>0.05)$ (Table 11). Drought stress significantly caused the reduction of TDM .Water stress negatively affect the TDM [23]. Increasing water stress caused a significant reduction of total dry matter (25-37\%) in maize crop [24]. Whereas the improvement dry matter contents with GA3 application might be due to its ameliorative effects on drought stress. Muszyńska et al., reported the similar findings and concluded that the exogenously applied GA3 during the early growth stage enhanced the endogenous phyto-hormone accumulation under drought conditions which not only protects enzymes but also supply energy for growth and survival thereby helping the plant to tolerate stress [25]. These results are in concordance with those of [26] foliar spray of GA3 found very effective adaptive strategy for achieving the higher biomass by allocating more dry matter through photosynthesis that ultimately is re-invested in accelerating foliage development at the vegetative stage. Similarly [Ashraf et al.,]reported that foliar application of selenium markedly improved the water status, chlorophyll contents and activated the anti-oxidant enzymes which eventually significantly influenced green fodder yield and quality of maize (Zea mays L.) under drought stressed conditions[22].

Table 11 Effect of different locations and combined levels of growth regulators on TDM ( $t$ ha-1) of maize fodder silage

\begin{tabular}{|c|c|c|c|c|c|c|}
\hline $\begin{array}{c}\text { Treatments / } \\
\text { Locations }\end{array}$ & \multicolumn{2}{|c|}{$\begin{array}{c}\text { NARC (Islamabad) } \\
\text { (Loc-1) }\end{array}$} & $\begin{array}{c}\text { URF Koont (Gujjar } \\
\text { Khan) } \\
\text { (Loc-2) }\end{array}$ & \multicolumn{2}{c|}{$\begin{array}{c}\text { GRS (Attock) } \\
\text { (Loc-3) }\end{array}$} \\
\hline Varieties & Afgoi & $\begin{array}{c}\text { Sohni Dharti- } \\
\mathbf{6 2 3}\end{array}$ & Afgoi & Varieties & Afgoi & Sohni Dharti-623 \\
\hline Control & $7.200 \mathrm{~ns}$ & $6.266 \mathrm{~ns}$ & $7.366 \mathrm{~ns}$ & $6.133 \mathrm{~ns}$ & $7.161 \mathrm{~ns}$ & $6.366 \mathrm{~ns}$ \\
\hline $\mathrm{GA}_{75}+\mathrm{Se}_{0.75}$ & $8.00 \mathrm{~ns}$ & $7.733 \mathrm{~ns}$ & $7.966 \mathrm{~ns}$ & $7.233 \mathrm{~ns}$ & $7.500 \mathrm{~ns}$ & $6.900 \mathrm{~ns}$ \\
\hline $\mathrm{GA}_{50}+\mathrm{Se}_{0.50}$ & $7.733 \mathrm{~ns}$ & $7.233 \mathrm{~ns}$ & $7.466 \mathrm{~ns}$ & $7.066 \mathrm{~ns}$ & $7.233 \mathrm{~ns}$ & $6.500 \mathrm{~ns}$ \\
\hline
\end{tabular}

\subsection{Total Digestible Nutrients (TDN) of Maize Fodder Silage}

Among locations, maize fodder grown at NARC and URF Koont (Loc-2) produced the highest TDN (57 and $56 \%$ ) respectively. The lowest quantity of TDN (54.178\%) was recorded at GRS, Attock (loc-3). More TDN was recorded in Afgoi (57.267\%) compared to Sohni Dahrti 623 (54.252\%) (Table 12). The comparison of the treatment means indicated that the highest TDN was recorded with the application of GA75+Se0.75 (56.972\%) followed by the application of GA50+Se0.50 (55.42\%). The lowest TDN value was found in control (54.833\%). The interactive effect of different locations and combined levels of growth regulators on TDN (\%) of maize fodder silage was found nonsignificant. Drought stress negatively influences the nutritive value of forages [27]. However the improved TDN with GA3 and Se application might be associated with their beneficial role in ameliorating the harmful effects of water stress at vegetative stage for improving yield and quality of fodder. Foliar application of GA3 under drought stress significantly reduced the negative effects of drought stress in maize[26]. The improved TDN with Se supplementation in our findings might be due to its potential role in mitigating the adverse effects of drought. The ameliorative role of Se was also reported by [28] The results of our study were further supported by the findings as reported by [Ormas and Vivas] that Se application under water deficit significantly affects the physiological and biochemical processes culminating into higher yield and quality of fodder in maize [32].

Table 12 Effect of different locations and combined levels of growth regulators on total digestible nutrients (TDN) of maize fodder silage

\begin{tabular}{|l|l|l|l|l|l|l|}
\hline \multicolumn{1}{|c|}{$\begin{array}{c}\text { Treatments / } \\
\text { Locations }\end{array}$} & \multicolumn{2}{|c|}{$\begin{array}{c}\text { NARC (Islamabad) } \\
\text { (Loc-1) }\end{array}$} & \multicolumn{1}{c|}{$\begin{array}{c}\text { URF Koont (Gujjar Khan) } \\
\text { (Loc-2) }\end{array}$} & \multicolumn{2}{c|}{$\begin{array}{c}\text { GRS (Attock) } \\
\text { (Loc-3) }\end{array}$} \\
\hline Varieties & Afgoi & $\begin{array}{l}\text { Sohni Dharti- } \\
\mathbf{6 2 3}\end{array}$ & Afgoi & Varieties & Afgoi & $\begin{array}{l}\text { Sohni Dharti- } \\
\text { 623 }\end{array}$ \\
\hline Control & $59.06 \mathrm{~ns}$ & $54.400 \mathrm{~ns}$ & $57.266 \mathrm{~ns}$ & $52.80 \mathrm{~ns}$ & $54.36 \mathrm{~ns}$ & $51.40 \mathrm{~ns}$ \\
\hline $\mathrm{GA}_{75}+\mathrm{Se}_{0.75}$ & $59.56 \mathrm{~ns}$ & $56.766 \mathrm{~ns}$ & $58.233 \mathrm{~ns}$ & $56.16 \mathrm{~ns}$ & $56.03 \mathrm{~ns}$ & $55.06 \mathrm{~ns}$ \\
\hline $\mathrm{GA}_{50}+\mathrm{Se}_{0.50}$ & $57.23 \mathrm{~ns}$ & $55.56 \mathrm{~ns}$ & $57.90 \mathrm{~ns}$ & $53.63 \mathrm{~ns}$ & $55.73 \mathrm{~ns}$ & $52.46 \mathrm{~ns}$ \\
\hline
\end{tabular}




\subsection{Crude Protein Contents (CP) of Maize Fodder Silage}

Among the locations, maize grown on the NARC produced highest crude protein (77.188 \%) followed by URF (6.8056\%). The lowest crude protein contents (6.305 \%) was accumulated at GRS, Attock. Maximum crude protein content was found in Afgoi (7.011\%) followed by Sohni Dahrti-623 (6.5222\%). Comparison of the treatment means showed that crude protein content was maximum with the application of GA75+Se $0.75(7.6389 \%)$ followed by application of GA50+Se0.50 (7.2167\%). The lowest crude protein contents value was under control condition (5.444\%). However the interactive effect of all the factors was found statistically non-significant ( $p>0.05$ ) (Table 13). Drought stress might have negatively affected the protein synthesis process in plants [29] reported that severe drought stress significantly decreased the crude protein contents. Under drought stress plants might have diverted most of its synthesized proteins to survive and not being used for growth leading to less accumulation of protein contents in the vegetative stage. The application of GA3 caused a significant reduction of the harmful effects of drought stress and markedly enhanced the growth of maize plants [30] similar findings that foliar application of GA3 significantly improved the depressed traits which eventually enhanced the vegetative growth in maize under drought. Water stress also negatively influenced the crude protein contents by limiting the nutrient (N) availability [23]. It was also cleared from our results that foliar application of Se also had significant effects on the accumulation crude protein contents when sown under different locations. The improved protein contents with Se might be due to its potential role as a mitigating agent under drought stress by positively influencing the physiological and chemical mechanisms including protein synthesis process [28]. Selenium supplementation markedly affects the physiological and bio-chemical processed to improve green fodder yield and quality of maize (Zea mays L.) under drought stress conditions which is very much consistent with our results.

Table 13 Effect of different locations and combined levels of growth regulators on crude protein contents (CP)of maize fodder silage

\begin{tabular}{|c|c|c|c|c|c|c|}
\hline $\begin{array}{c}\text { Treatments / } \\
\text { Locations }\end{array}$ & \multicolumn{2}{|c|}{$\begin{array}{c}\text { NARC (Islamabad) } \\
\text { (Loc-1) }\end{array}$} & $\begin{array}{c}\text { URF Koont (Gujjar Khan) } \\
\text { (Loc-2) }\end{array}$ & \multicolumn{2}{c|}{$\begin{array}{c}\text { GRS (Attock) } \\
\text { (Loc-3) }\end{array}$} \\
\hline Varieties & Afgoi & $\begin{array}{c}\text { Sohni Dharti- } \\
\mathbf{6 2 3}\end{array}$ & Afgoi & Varieties & Afgoi & $\begin{array}{c}\text { Sohni } \\
\text { Dharti-623 }\end{array}$ \\
\hline Control & $6.13 \mathrm{~ns}$ & $6.2 \mathrm{~ns}$ & $5.80 \mathrm{~ns}$ & $5.36 \mathrm{~ns}$ & $4.7 \mathrm{~ns}$ & $4.46 \mathrm{~ns}$ \\
\hline $\mathrm{GA}_{75}+\mathrm{Se}_{0.75}$ & $8.06 \mathrm{~ns}$ & $8.03 \mathrm{~ns}$ & $7.93 \mathrm{~ns}$ & $7.13 \mathrm{~ns}$ & $7.6 \mathrm{~ns}$ & $7.00 \mathrm{~ns}$ \\
\hline $\mathrm{GA}_{50}+\mathrm{Se}_{0.50}$ & $7.66 \mathrm{~ns}$ & $7.03 \mathrm{~ns}$ & $7.76 \mathrm{~ns}$ & $6.83 \mathrm{~ns}$ & $7.366 \mathrm{~ns}$ & $6.63 \mathrm{~ns}$ \\
\hline
\end{tabular}

\subsection{Neutral Detergent Fiber (\%) (NDF) of Maize Fodder Silage}

Maize fodder grown at NARC (Loc-1) produced the highest NDF (59.872\%) and similarly also at the URF, Koont (58.322 $\%$ ).The lowest quantity of neutral detergent fiber was accumulated (56.061\%) at Attock (Loc-3).Moreover between the varieties, the maximum neutral detergent fiber was in Afgoi (59.422\%) followed by Sohni Dahrti-623 (56.748\%). Comparison of the treatment means showed that neutral detergent fiber was maximum by the application of GA75+Se $0.75(60.978 \%)$ followed application of GA50+Se0.50 (58.206\%). The lowest neutral detergent fiber contents value was in control condition (55.072\%). However the interactive effect of all the factors was found statistically nonsignificant ( $p>0.05$ ) (Table 14). Neutral detergent fibers (hemicelluloses, cellulose, and lignin) are considered to be the important characteristics of forage quality [31]. Neutral detergent fiber (NDF) is a measure of fiber after digestion in a neutral detergent as an aid in determining the quality and digestibility of forages. High quality forages have low concentrations of NDF which determine the intake and digestibility of fodder [32].

Table 14 Effect of different locations and combined levels of growth regulators on neutral detergent fiber (\%) of maize fodder silage

\begin{tabular}{|c|c|c|c|c|c|c|}
\hline $\begin{array}{c}\text { Treatments / } \\
\text { Locations }\end{array}$ & \multicolumn{2}{|c|}{$\begin{array}{c}\text { NARC (Islamabad) } \\
\text { (Loc-1) }\end{array}$} & $\begin{array}{c}\text { URF Koont (Gujjar Khan) } \\
\text { (Loc-2) }\end{array}$ & \multicolumn{2}{c|}{$\begin{array}{c}\text { GRS (Attock) } \\
\text { (Loc-3) }\end{array}$} \\
\hline Varieties & Afgoi & $\begin{array}{c}\text { Sohni } \\
\text { Dharti-623 }\end{array}$ & Afgoi & Varieties & Afgoi & $\begin{array}{c}\text { Sohni } \\
\text { Dharti-623 }\end{array}$ \\
\hline Control & $58.433 \mathrm{~ns}$ & $56.466 \mathrm{~ns}$ & $55.866 \mathrm{~ns}$ & $54.166 \mathrm{~ns}$ & $53.766 \mathrm{~ns}$ & $51.733 \mathrm{~ns}$ \\
\hline GA75+Se0.75 & $62.833 \mathrm{~ns}$ & $61.433 \mathrm{~ns}$ & $62.566 \mathrm{~ns}$ & $60.100 \mathrm{~ns}$ & $61.933 \mathrm{~ns}$ & $57.00 \mathrm{~ns}$ \\
\hline GA50+Se0.50 & $60.833 \mathrm{~ns}$ & $59.233 \mathrm{~ns}$ & $61.366 \mathrm{~ns}$ & $55.866 \mathrm{~ns}$ & $57.200 \mathrm{~ns}$ & $54.733 \mathrm{~ns}$ \\
\hline
\end{tabular}


Water stress significantly increased the neutral detergent fiber (NDF) leading to the deteriorated forage quality. In the present study the decreased NDF contents were found with the application GA3 and Se might be attributed to improved water status and increased activity of antioxidant machinery that would have stimulated uptake of minerals and translocation of assimilates to shoot which enhanced the herbage quantity and reduced the NDF contents of forage. Foliar application of both viz., GA3 and Se have beneficial role in mitigating harmful effects of water stress on various physiological and biochemical processes which resultantly improve the vegetative growth and herbage quality by reducing NDF contents under drought stress[30-28].

\subsection{Crude Fiber (CF) of Maize Fodder Silage}

Among the sites, maize grown on the NARC (loc-1) produce highest crude fiber content was (28.850 \%) and followed by the Koont URF (Chakwal road) (loc-2) (27.356\%) and (26.239\%) at Attock (Table 15).Moreover between the varieties, the maximum crude fiberwas in Afgoi (60.978 \%) followed by Sohni Dahrti-623 (58.206\%). Comparison of the treatment means showed that crude fiber was maximum by the application of GA75+Se $0.75(28.850 \%)$ followed application of GA50+Se0.50 (27.356\%) and under control condition (26.239\%). However the interactive effect of all the factors was found statistically non-significant $(\mathrm{p}>0.05)$. Availability of proper proportion of crude fiber in daily feed intake plays a vital role in animal health. The crude fiber comprises the neutral detergent fiber (NDF) and acid detergent fiber (ADF). Drought stress disturbed this proportion adversely which significantly influenced the green forage intake and its digestibility. In our results NDF and ADF were significantly increased which were in line with [24] Seif et al. (2016) who reported that both ADF and NDF followed the incremental trend with increasing water stress. Further, these results of the present study were contradictory with [33] that reduced contents of ADF and NDF of forage legumes under drought stress. According to [Newman] an association between the improvement of corn plant ADF and NDF content with drought stress [34]. In the present study the reduced crude fiber contents (ADF \& NDF) were found with the application GA3 and Se might be the cause of enhanced antioxidant enzymes activities and improved water contents that would have stimulated uptake of minerals and translocation of assimilates to shoot which reduced the fiber contents and increased the herbage. The results of our study were in line with [Nawaz et al.,] that the foliar application of Se significantly increased the crude fiber by activating enzymes activity and stimulating the uptake of minerals and translocation of assimilates to shoot which enhanced fodder quality [28]. Our results were also concordant with the [30]. Physiological processes and biochemical activities including enzyme activation that increased the elemental uptake leading to improved nutritional status of plants.

Table 15 Effect of different locations and combined levels of growth regulators on Crude fiber (\%) of maize fodder silage

\begin{tabular}{|c|c|c|c|c|c|c|}
\hline $\begin{array}{c}\text { Treatments / } \\
\text { Locations }\end{array}$ & \multicolumn{2}{|c|}{$\begin{array}{c}\text { NARC (Islamabad) } \\
\text { (Loc-1) }\end{array}$} & $\begin{array}{c}\text { URF Koont (Gujjar Khan) } \\
\text { (Loc-2) }\end{array}$ & \multicolumn{2}{c|}{$\begin{array}{c}\text { GRS (Attock) } \\
\text { (Loc-3) }\end{array}$} \\
\hline Varieties & Afgoi & $\begin{array}{c}\text { Sohni Dharti- } \\
\mathbf{6 2 3}\end{array}$ & Afgoi & Varieties & Afgoi & $\begin{array}{c}\text { Sohni } \\
\text { Dharti-623 }\end{array}$ \\
\hline Control & $28.4 \mathrm{~ns}$ & $25.93 \mathrm{~ns}$ & $27.16 \mathrm{~ns}$ & $26.16 \mathrm{~ns}$ & $25.46 \mathrm{~ns}$ & $25.53 \mathrm{~ns}$ \\
\hline $\mathrm{GA}_{75}+\mathrm{Se}_{0.75}$ & $31.3 \mathrm{~ns}$ & $30.20 \mathrm{~ns}$ & $29.36 \mathrm{~ns}$ & $26.26 \mathrm{~ns}$ & $28.66 \mathrm{~ns}$ & $25.53 \mathrm{~ns}$ \\
\hline $\mathrm{GA}_{50}+\mathrm{Se}_{0.50}$ & $29.8 \mathrm{~ns}$ & $27.40 \mathrm{~ns}$ & $27.63 \mathrm{~ns}$ & $27.53 \mathrm{~ns}$ & $26.33 \mathrm{~ns}$ & $25.90 \mathrm{~ns}$ \\
\hline
\end{tabular}

\subsection{Acid Detergent Fiber (\%) (ADF) of Maize Fodder Silage}

Among the locations, maize grown at NARC (loc-1) produced the highest Acid detergent fiber was (36.950 \%) and at URF Koont (36.853\%). However the least quantity of Acid detergent fiber was observed at Attock (34.700\%). Moreover between the varieties, the maximum Acid detergent fibre was in Afgoi (37.074 \%) followed by Sohni Dahrti-623 (35.261\%). Comparison of the treatment means showed that Acid detergent fiber was maximum by the application of GA75+Se0.75 produced (37.489\%) crude fiber and statistically similar quality produced by application of GA50+Se0.50 (36.514\%). However least value was observed in under control condition (34.500\%) (Table 16). However the interactive effect of all the factors was found statistically non-significant ( $p>0.05)$. Acid detergent fiber (ADF) is the less digestible portion of the forage, containing cellulose, lignin and heat damaged protein. ADF is chosen as indicator for determining the nutritive value of the forage and closely related to the digestibility of forages. Lower ADF implies the forage is more digestible. Hence, a lower concentration of ADF is desirable. Drought stress caused a significant increase in the ADF contents [29] which is very much consistent with our findings of [Liu et al.,] but contradictory with the findings as reported by [Bahreininejad] that drought stress may cause reduction of ADF concentration [35]. The results of our study were further in confirmatory with [Newman] that drought stress deteriorated the forage quality [34]. While 
the improvement of forage quality with the application of GA3 and Se might be due their possible role in the alleviation of adverse effects of drought stress by regulating the physiological and biochemical mechanisms at vegetative stage. The ameliorative effects of GA3 application in maize under drought stress were also reported by [30]. Similar findings were also reported by [Nawaz et al.,] that exogenous application of Se significantly improved the fodder yield and quality in maize under water deficit conditions [28], which were found very close to the present results. The results of the present study were further supported with the reports of [Kale et al.,] that different nitrogen doses significantly reduced the ADF concentration in maize under irrigation stressed conditions [23].

Table 16 Effect of different locations and combined levels of growth regulators on Acid detergent fiber (\%) (ADF) of maize fodder silage

\begin{tabular}{|c|c|c|c|c|c|c|}
\hline $\begin{array}{c}\text { Treatments / } \\
\text { Locations }\end{array}$ & \multicolumn{2}{|c|}{$\begin{array}{c}\text { NARC (Islamabad) } \\
\text { (Loc-1) }\end{array}$} & $\begin{array}{c}\text { URF Koont (Gujjar Khan) } \\
\text { (Loc-2) }\end{array}$ & \multicolumn{2}{c|}{$\begin{array}{c}\text { GRS (Attock) } \\
\text { (Loc-3) }\end{array}$} \\
\hline Varieties/hybrids & Afgoi & $\begin{array}{c}\text { Sohni } \\
\text { Dharti-623 }\end{array}$ & Afgoi & $\begin{array}{c}\text { Sohni } \\
\text { Dharti-623 }\end{array}$ & Afgoi & $\begin{array}{c}\text { Sohni } \\
\text { Dharti-623 }\end{array}$ \\
\hline Control & $36.933 \mathrm{~ns}$ & $31.433 \mathrm{~ns}$ & $36.466 \mathrm{~ns}$ & $34.80 \mathrm{~ns}$ & $33.500 \mathrm{~ns}$ & $33.866 \mathrm{~ns}$ \\
\hline $\mathrm{GA}_{75}+\mathrm{Se}_{0.75}$ & $39.466 \mathrm{~ns}$ & $38.633 \mathrm{~ns}$ & $38.366 \mathrm{~ns}$ & $37.166 \mathrm{~ns}$ & $37.466 \mathrm{~ns}$ & $33.833 \mathrm{~ns}$ \\
\hline $\mathrm{GA}_{50}+\mathrm{Se}_{0.50}$ & $38.533 \mathrm{~ns}$ & $36.70 \mathrm{~ns}$ & $37.566 \mathrm{~ns}$ & $36.75 \mathrm{~ns}$ & $35.366 \mathrm{~ns}$ & $34.166 \mathrm{~ns}$ \\
\hline
\end{tabular}

\subsection{Ash Contents (\%) of Maize Fodder Silage}

Application of different treatments, varieties and sites had significant effect on ash contents (\%). Among the sites, maize grown on the NARC produce highest ash contents was (7.4611\%) and at URF Koont (7.1278\%). However the least quantity of ash contents were observed at Attock (loc-3) (6.6889\% (Table 17). Moreover between the varieties, the maximum ash contents was in Afgoi (7.2481\%) followed by Sohni Dahrti-623 (6.9370\%). Comparison of the treatment means showed that ash contents was maximum by the application of GA75+Se $0.75(7.5556 \%)$ and by application of GA50+Se0.50 (7.2444\%). However least value was observed in under control condition (6.4778 \%). However, the interactive effect of all the factors was found statistically non-significant ( $p>0.05)$. Ash residues is composed of various types of minerals usually phosphorus and calcium but it also contain other minerals such as iron and zinc. Since these minerals are an important part of the animal's diet, some ash is desirable. On the other hand, too much may end up causing crystals to form in the urinary tract leading to various kidney diseases in animals. Therefore, fodder with higher ash contents should be avoided. In an experiment conducted by Kale et al. (2014) it was concluded that water stress along with higher doses of nitrogen significantly increased the crude ash contents in maize[23]. In our findings the decreased contents of ash with the foliar application of GA3 and Se might be due to their more enzymatic activity promoting function under drought stress than enhancing the mineral uptake. The findings of the [ confirmed our results where they investigated that foliar application of Se had no significant effect on the ash contents was due to its prominent role in the stimulation of various enzymatic activities in maize under water deficit [28]. Similarly the potential role of GA3 in regulating the enzymatic activities under drought stress was also reported by [30], which support the view that both GA3 and Se reduced the ash contents by regulating enzymatic activities specially and enhancing mineral uptake generally under stress conditions.

Table 17 Effect of different locations and combined levels of growth regulators on Ash contents (\%)of maize fodder silage

\begin{tabular}{|c|c|c|c|c|c|c|}
\hline $\begin{array}{c}\text { Treatments / } \\
\text { Locations }\end{array}$ & \multicolumn{2}{|c|}{$\begin{array}{c}\text { NARC (Islamabad) } \\
\text { (Loc-1) }\end{array}$} & \multicolumn{2}{c|}{$\begin{array}{c}\text { URF Koont (Gujjar } \\
\text { Khan) } \\
\text { (Loc-2) }\end{array}$} & \multicolumn{2}{c|}{$\begin{array}{c}\text { GRS (Attock) } \\
\text { (Loc-3) }\end{array}$} \\
\hline Varieties & Afgoi & $\begin{array}{c}\text { Sohni Dharti- } \\
\mathbf{6 2 3}\end{array}$ & Afgoi & Varieties & $\begin{array}{c}\text { Afgoi } \\
\text { Dharti- } \\
\mathbf{6 2 3}\end{array}$ \\
\hline Control & $7.001 \mathrm{~ns}$ & $6.300 \mathrm{~ns}$ & $6.733 \mathrm{~ns}$ & $6.466 \mathrm{~ns}$ & $6.433 \mathrm{~ns}$ & $5.933 \mathrm{~ns}$ \\
\hline $\mathrm{GA}_{75}+\mathrm{Se}_{0.75}$ & $8.133 \mathrm{~ns}$ & $7.933 \mathrm{~ns}$ & $7.800 \mathrm{~ns}$ & $7.466 \mathrm{~ns}$ & $7.133 \mathrm{~ns}$ & $6.866 \mathrm{~ns}$ \\
\hline $\mathrm{GA}_{50}+\mathrm{Se}_{0.50}$ & $7.766 \mathrm{~ns}$ & $7.633 \mathrm{~ns}$ & $7.200 \mathrm{~ns}$ & $7.100 \mathrm{~ns}$ & $7.033 \mathrm{~ns}$ & $6.733 \mathrm{~ns}$ \\
\hline
\end{tabular}




\subsection{Eather Extract of Maize Fodder Silage}

Results revealed that the maximum ether extract was recorded in Afgoi (1.92\%) followed by Sohni Dharti (1.83 \%). Among the growth regulators, the highest ether extract was found with GA75+Se0.75 (1.98\%) followed by GA50+Se0.50 $(1.90 \%)$. The lowest ether extract $(1.74 \%)$ was obtained in the control treatment. The lowest dry matter $\left(6.75 \mathrm{tha}{ }^{-1}\right)$ was obtained in the control treatment (Table 18). The interactive effect of all the factors was found statistically nonsignificant ( $p>0.05)$. The findings of the present study are similar to that of [36] that application of growth.

Table 18 Effect of different locations and combined levels of growth regulators on Ether Extract (\%) of maize fodder silage

\begin{tabular}{|c|c|c|c|c|c|c|}
\hline $\begin{array}{c}\text { Treatments / } \\
\text { Locations }\end{array}$ & \multicolumn{2}{|c|}{$\begin{array}{c}\text { NARC (Islamabad) } \\
\text { (Loc-1) }\end{array}$} & \multicolumn{2}{c|}{$\begin{array}{c}\text { URF Koont (Gujjar } \\
\text { Khan) (Loc-2) }\end{array}$} & \multicolumn{2}{c|}{$\begin{array}{c}\text { GRS (Attock) } \\
\text { (Loc-3) }\end{array}$} \\
\hline Varieties & Afgoi & $\begin{array}{c}\text { Sohni } \\
\text { Dharti-623 }\end{array}$ & Afgoi & Varieties & Afgoi & $\begin{array}{c}\text { Sohni } \\
\text { Dharti-623 }\end{array}$ \\
\hline Control & $1.820 \mathrm{~ns}$ & $1.720 \mathrm{~ns}$ & $1.7633 \mathrm{~ns}$ & $1.693 \mathrm{~ns}$ & 1.7266 & $1.693 \mathrm{~ns}$ \\
\hline $\mathrm{GA}_{75}+\mathrm{Se}_{0.75}$ & $2.1266 \mathrm{~ns}$ & $1.930 \mathrm{~ns}$ & $2.046 \mathrm{~ns}$ & $1.853 \mathrm{~ns}$ & 2.0166 & $1.93 \mathrm{~ns}$ \\
\hline $\mathrm{GA}_{50}+\mathrm{Se}_{0.50}$ & $1.953 \mathrm{~ns}$ & $1.916 \mathrm{~ns}$ & $1.936 \mathrm{~ns}$ & $1.9166 \mathrm{~ns}$ & $1.8933 \mathrm{~ns}$ & $1.773 \mathrm{~ns}$ \\
\hline
\end{tabular}

\section{Conclusion}

It could be concluded that maize is an exceptional crop which could effectively be utilized as a feed and fodder crops to meet the increasing demands of livestock. In rainfed areas of Pothwar, the climatic conditions at NARC, Islamabad were more conducive for fodder/grain maize productions compared to URF Koont (Gujjar Khan) and Groundnut Research Station, Attock. Growth and Agro-morphological parameters of maize fodder crop (plant height, fresh biomass, leaf area index at 30 and at 60 days, leaf area duration, net assimilation rate, and crop growth rate) had the highest values of these traits for the crop planted at NARC, Islamabad followed by URF Koont, Gujjar Khan (Loc-2). The growth and agronomic performance was observed better in Afgoi as compared to Sohni Dharti 623. Overall the combined levels of growth regulators $(\mathrm{GA} 3+\mathrm{Se})$ gave maximum results with combination GA75+Se0.75 than with the GA50+Se0.50 and control. Fresh biomass and leaf area at 60 DAS were found the highest with application@ GA75+Se0.75 followed by GA50+Se0.50. Between the varieties/hybrids total dry matter (TDM), total digestible nutrients (TDN), crude protein (CP), neutral detergent fiber (NDF), Crude fiber acid detergent fiber (ADF), ash contents were found the higher in Afgoi than Sohni Dharti 623. Among locations, the TDM, TDN (\%), neutral detergent fiber, acid detergent fiber, ash contents were recorded more at NARC followed by URF Koont. But the GRS, Attock remained at the bottom. The crude fiber was recorded as the highest at NARC followed by URF Koont and GRS, Attock which were comparable to each other. Among the growth regulators, the highest levels of TDM, crude protein, TDN, CF and neutral detergent fiber, ADF and ash contents were found with the application of GA75+Se0.75 with least in control.

\section{Compliance with ethical standards}

\section{Acknowledgments}

We acknowledge Pakistan Agriculture Research Council for providing financial assistant to conduct experiment.

\section{Disclosure of conflict of interest}

The authors proclaim that there is no conflict of interests regarding the publication of this paper

\section{References}

[1] Mehmood T, Liu C, Niazi NK, Gaurav GK, Ashraf A, Bibi I. Compost-mediated arsenic phytoremediation, health risk assessment and economic feasibility using Zea mays L. in contrasting textured soils. International Journal of Phytoremediation. 2021; 23(9): 899-910.

[2] Rehman A, Jingdong, L, Chandio AA, Hussain I. Livestock production and population census in Pakistan: Determining their relationship with agricultural GDP using econometric analysis. 2017; 4(2): 168-177. 
[3] Sajjad A, Lu J, Chen X, Chisenga C. Mahmood S. The riverine flood catastrophe in August 2010 in South Punjab, Pakistan: Potential causes, extent and damage assessment. Applied ecology and environmental research. 2019; 17: 14121-14142.

[4] Habermann E, Dias DO, EA, Contin DR, Delvecchio G, Viciedo, DO, De MMA, Martinez, CA. Warming and water deficit impact leaf photosynthesis and decrease forage quality and digestibility of a C4 tropical grass. Physio. Plantarum.2019; 165(2) : 383-402.

[5] Chan DB, Dija B, Subash B, Keshav B, Arvind S, Bidya, KS. Factors affecting the productivity of coffee in gulmi and arghakhanchi districts of Nepal. Journal of agriculture and natural resources. 2020; 3(1): 51-60.

[6] GOP. Economic Survey of Pakistan. Govt. of Pakistan finance division ecology advisory, Wing, Islamabad. 2018; 503.

[7] Yusuff O, Rafii MY, Abdullah N, Magaji U, Hussin G. Ramli A, Miah G. Fermentation Quality and Additives: A Case of Rice Straw Silage, Bio medical Research International. 2016.

[8] Wang J, Wang Z, Mao H, Zhao H, and Huang D. Increasing Se concentration in maize grain with soil- or foliarapplied selenite on the Loess Plateau in China. Field crops research. 2013; 50: 83-90.

[9] Bremner. Organic forms of nitrogen. In C.A. Black et al., (eds), Methods of soil analysis, Part. American society of Agronomy. Inc., Medison, Wisconson. 1964; 9: 1235-1255.

[10] Harris LE. Nutrition Research Techniques for domestic and wild animals. Animal science. Utah State University, Logen, Utah, USA. 1970; 1.

[11] Wardeh MF. Models for estimating energy and protein utilization for feeds. Ph.D. Thesis. 1981.

[12] Auler AC, Cássaro FAM, Da SVO, Pires LF. Evidence that high temperatures and intermediate relative humidity might favor the spread of COVID-19 in tropical climate: A case study for the most affected Brazilian cities. Science of the total environment. 2020; 729: 9090.

[13] Parkes B, Higginbottom TP, Hufkens, Ceballos F, Kramer B, Foster T. Weather dataset choice introduces uncertainty to estimates of crop yield responses to climate variability and change. Environmental Research Letters. 2019; 14(12):124089.

[14] Baum ME, Archontoulis SV. Licht MA. Planting date, hybrid maturity, and weather effects on maize yield and crop stage. Agronomy journal. 2019; 111(1): 303-313.

[15] Mishra GC, Avinash K, Duvvada SK, Supriya B, Mishra G, Satapathy A. Response of hybrid sweet corn (Zea mays) to fertility levels with and without GA3 on production potential and economics in Southern Odisha. J.Pharm. and Phytochem. 2020; 9(4): 242-245.

[16] Al-Shaheen MR, Soh A. Effect of proline and gibberellic acid on the qualities and qualitative of corn (Zea maize L.) under the influence of different levels of the water stress. International Journal of Scientific and Research Publications. 2016; 6(5): 752-756.

[17] Hutsch BW, Schubert S. Maize harvest index and water use efficiency can be improved by inhibition of gibberellins biosynthesis. Journal of Agronomy and Crop Science. 2018; 204(2): 209-218.

[18] Nelissen H, Sun XH, Rymen, B, Jikumaru Y, Kojima M, Takebayashi Y, Inze D. The reduction in maize leaf growth under mild drought affects the transition between cell division and cell expansion and cannot be restored by elevated gibberellic acid levels. Plant biotechnology journal. 2018; 16(2): 615-627.

[19] Rehman A, Jingdong L, Chandio AA, Hussain I. Livestock production and population census in Pakistan: Determining their relationship with agricultural GDP using econometric analysis. 2017; 4(2): 168-177.

[20] Sarwar NO, Farooq K, Mubeen, A. Wasaya W, Nouman MZ, Ali, Shehzad. M. Exogenous Application of Gibberellic Acid Improves the Maize Crop Productivity Under Scarce and Sufficient Soil Moisture Condition. Cercetari Agronomic in Moldova. 2017; 50(4): 65-73.

[21] Rafique M, Naveed M, Mustafa A, Akhtar S, Munawar M, Kaukab S, Salem MZ. The combined effects of gibberellic ; acid and rhizobium on growth, yield and nutritional status in chickpea (Cicer arietinum L.). Agronomy. 2021; 11(1): 105.

[22] Ashraf MA, Akbar A, Parveen A, Rasheed R, Hussain I. Iqbal, M. Phonological application of selenium differentially improves growth, oxidative defense and ion homeostasis in maize under salinity stress. Plant Physiology and Biochemistry. 2018; 123: 268-280. 
[23] Kale H, Kaplan M, Ulger I, Unlukara A, Akar T. Feed value of maize (Zea mays var. Indentata (sturtev.) L.h.bailey) grain under different irrigation levels and nitrogen doses. Turk Journal of field crops. 2018; 23(1): 56-61.

[24] Seif F, Paknejad F, Azizi F, Kashani AM. Shahabifar. Effect of different irrigation regimes and zeolite application on yield and quality of silage corn hybrids .Journal of experimental biology and agricultural Sciences. 2016; 4(VIS): 721-729.

[25] Muszyńska E, Labudda M, Rozanska E, Hanus FE, Znojek E. Heavy metal tolerance in contrasting ecotypes of Alyssum montanum. Ecotoxicology and environmental safety. 2018; 161: 305-317.

[26] Ullah S, Anwar S, Rehman M, Khan, S, Zafar S, Liu L, Peng, D. Interactive effect of gibberellic acid and NPK fertilizer combinations on ramie yield and bast fibre quality. Scientific reports. 2017; 7(1): 1-9.

[27] Bibi A, Sadaqat HA, Tahir MHN. Akram, HM. Screening of sorghum (Sorghum bicolor var. Moench) for drought tolerance at seedling stage in polyethylene glycol. Journal animal and plant sciences. 2012; 22: 671-678.

[28] Nawaz F, Ashraf MY, Ahmad R, Waraich EA, Shabbir RN, Bukhari MA. Supplemental selenium improves wheat grain yield and quality through alterations in biochemical mical processes under normal and water deficit conditions. Food chemistry. 2016; 175: 350-357.

[29] Liu Y, Wu Q, Ge G, Han G. Jia Y. Influence of drought stress on afalfa yields and nutritional composition. BMC Plant biology. 2018; 18: 13-21.

[30] Akter N, Islam MR, Karim MA, Hossain T. Alleviation of drought Stress in Maize by Exogenous Application of Gibberellic Acid and Cytokinin. Journal of crop Science biotechnology. 2014; 17(1): 41-48.

[31] Habermann E, Dias DOEA, Contin DR, Delvecchio G, Viciedo DO, de MA, Martinez CA. Warming and water deficit impact leaf photosynthesis and decrease forage quality and digestibility of a C4 tropical grass. Physio. Plantarum. 2019; 65 (2): 383-402.

[32] Oramas WC, Vivas QNJ. Evaluation of two hybrids and one variety of corn (Zea mays) in intensive crop and association with pean (Phaseolus vulgaris), for silage. Revista de la Facultad de Ciencias Agropecuarias. 2007; 5(1): 28-35.

[33] Kuchenmeister K, Kuchenmeister F, Kayser M, Wrage MN. Isselstein Influence of drought stress on nutritive value of perennial forage legumes. International journal of Plant Production. 2013; 693-710.

[34] Newman MA. Defining the energy and nutrient content of corn grown in drought-stressed conditions and determining the relationship between energy content of corn and the response of growing pigs to xylanase supplementation. MSc thesis submitted to the Iowa State University. 2014; 5-25.

[35] Bahreininejad B. Effects of water stress on growth parameters and forage quality of globe artichoke (Cynara cardunculus var. scolymus L.). Iran Agricultural Research. 2019; 38(2): 101-110. 